\title{
Evaluate the Integrated Nutrient Use on Growth and Yield of Hybrid Maize under Central Plain Zone of Uttar Pradesh, India
}

\author{
Durgesh Kumar*, Munish Kumar and Raj Kumar \\ Department of Soil conservation and Water Management, C.S.A. University of Agriculture \\ and Technology Kanpur-208002, India \\ *Corresponding author
}

\section{A B S T R A C T}

\begin{tabular}{|l|}
\hline Ke y w or d s \\
Growth and yield, \\
Maize, Nutrient
\end{tabular}

\section{Introduction}

Maize is an important crop in India and ranked fifth in area, fourth in production and third in productivity. In term of world acreage, India stands only next to USA, Brazil, China and Maxico, where as in production it ranks $11^{\text {th }}$. Maize is predominant crop of tribal area of southern part of India, where it is used as food and feed. Normal maize, have poor nutritional value because of lower contents of essential amino-acids such as lysine and tryptophan. But quality protein maize contains higher amount of these amino acids in the endosperm than normal maize. The balance combination of amino acids in quality protein maize results in to its higher biological value ensuring more availability of protein to human and animal as compared to normal maize. The productivity of quality protein maize is low due to inherent low soil fertility and poor nutrient management practices like- low use of inorganic fertilizers, no use of organic manures, poor recycling of crop residue and no use of secondary and micronutrient in tribal region. The conjunctive use of organic manure and chemical fertilizers can augment the nutrient use efficiency and also enhance the productivity of quality protein maize (Kumar et al., 2005).

Maize occupies an area about 7.7 million hectare in India with production of 13.85 million tonnes resulting of $17.83 \mathrm{q} / \mathrm{ha}$. Andhra Pradesh ranks $\mathrm{I}^{\text {st }}$ in productivity with 51.25 q/ha followed by Rajasthan with 26.67 q/ha. 
With respect to Uttar Pradesh, the area, production and productivity is about 0.94 million hectare, 1.57 million tonnes and 16.10 q/ha, respectively. In Uttar Pradesh, cultivation of winter maize is concentrated in eastern parts. Bihar ranks first place in respect of area of winter maize (190.7 thousand hectare) followed by Andhra Pradesh (185.1 thousand hectare) and Tamilnadu (183.3 thousand hectare). However, Andhra Pradesh ranks first in term of production (574.0 thousand tonnes) followed by Karnataka (485.1 thousand tonnes) while, Andhra Pradesh gained first positioning respect of winter maize productivity $(5125 \mathrm{~kg} / \mathrm{ha})$ followed by Karnataka (3267 kg/ha).

A number of maize hybrids are being developed. Grain yield is important criteria for selection of hybrids in maize breeding programme. To make selection for grain yield effective which is a complex phenomenon and interdependent on various other yield contributing factors, it is highly essential to study the association between the yields contributing factors and grain yield.

\section{Materials and Methods}

A field experiment was conducted during Kharif season of 2016 at Soil Conservation and Water Management Farm of the Chandra Shekhar Azad University of Agriculture and Technology, Kanpur. Geographical Situation and Climate Kanpur is situated in the central part of Uttar Pradesh at an elevation of 129.0 meters above the Mean Sea Level. It lies between $25^{\circ} 26^{\prime}$ and $26^{\circ} 58^{\prime}$ North latitude and $79^{\circ} 31^{\prime}$ and $80^{\circ} 34^{\prime}$ East longitude. The Kanpur district falls in the sub-tropical zone having semi-arid climate. The weather data regarding to total rainfall (351.1), average maximum (32.80) and average minimum (25.24) temperatures, relative average humidity maximum (88.0), average humidity minimum (74.0), average wind speed $(\mathrm{km} / \mathrm{hr})$
(5.12) and average evaporation rate (mm/day) (3.97) for the experimental period as recorded at the University's Meteorological Observatory. The experiment was carried out in Randomized Block Design (RBD) with the three replications having 09 treatments combination which are allocated randomly in all plots. The details of treatments are given below.

\section{A. Levels of inorganic fertilizer - 3}

$100 \%$ R.D.F. $(100+60+40+20) \mathrm{F}_{1}$

$75 \%$ RDF $(75+45+30+15) \mathrm{F}_{2}$

$50 \%$ RDF $(50+30+20+10) \mathrm{F}_{3}$

\section{B. Levels of organic manure - 3}

15 ton $\mathrm{FYM} / \mathrm{ha} \mathrm{O}_{1}$ 20 ton $\mathrm{FYM} / \mathrm{ha} \mathrm{O}_{2}$ 25 ton $\mathrm{FYM} / \mathrm{ha} \mathrm{O}_{3}$

\section{Results and Discussion}

\section{Plant population (000' ha $^{-1}$ )}

The data on plant population (Initial and harvest) are presented in table - 1

\section{Initial plant stand $\left(000^{\prime} \mathrm{ha}^{-1}\right)$}

The initial plant stand recorded after completion of germination and final plant thinning and data revealed that the different treatments methods and fertility management practices were non significantly affected in initial plant population.

The fertility management practices also influenced plant population at all the treatments. When the treatment incombination of inorganic 100 percentage RDF with organic $25 \mathrm{t} / \mathrm{ha}$ FYM shows the superior performance. The highest plant stand from at initial stage $\left(164.550 \mathrm{ha}^{-1}\right)$ was found with the treatment $100 \% \mathrm{RDF}$ and $163.237000 \mathrm{ha}^{-1}$ 
was found under the treatment $25 \mathrm{t} / \mathrm{ha} \mathrm{FYM}$ and the lowest $\left(161.347000 \mathrm{ha}^{-1}\right)$ was recorded under $50 \%$ RDF and $162.610000 \mathrm{ha}^{-1}$ was recorded as 15 t/ha FYM) respectively. Germination percentage is severely affected by combined application of RDF and FYM.

\section{Final plant stand $\left(000^{\prime} \mathrm{ha}^{-1}\right)$}

The variations in the final plant population due to fertility management were found nonsignificant. The highest plant stand was found under $\mathrm{F}_{1}$ and $\mathrm{O}_{3}(100 \% \mathrm{RDF}$ and $25 \mathrm{t} / \mathrm{ha}$ FYM) the treatment and the lowest was found under $\mathrm{F}_{3}$ and $\mathrm{O}_{3}(50 \% \mathrm{RDF}$ and $25 \mathrm{t} / \mathrm{h} \mathrm{FYM}$ respectively.

\section{Growth characters}

\section{Plant height}

The data on plant height recorded at 30, 60 DAS and at maturity stage starting from 30 days after sowing to harvest are presented in table -1 and Figure 1. Fertilizer management practices significantly influenced the plant height at 30, 60 days and at maturity. The height of plant subjected to $\mathrm{F}_{1}$ and $\mathrm{O}_{3}(100 \%$ RDF and 25t FYM/ ha) was consistently taller than the plants in fertility management practices treatments. The tallest plants height in $\mathrm{F}_{1}$ and $\mathrm{O}_{3}(100 \%$ RDF and 25t FYM/ ha) treatment were recorded a tall stage, than the other treatment. The plant height at maturity were $244.00 \mathrm{~cm}$ and $242.78 \mathrm{~cm}$ under $\mathrm{F}_{1}$ and $\mathrm{O}_{3}(100 \% \mathrm{RDF}$ and 25t FYM/ ha) whereas lower in $\mathrm{F}_{3}$ and $\mathrm{O}_{1}(50 \% \mathrm{RDF}$ and $15 \mathrm{t} / \mathrm{ha}$ FYM) i.e. $239.89 \mathrm{~cm}$ and 161.24, respectively. Similar findings have also been reported by Mohammed et al., (2014).

\section{Number of functioning leaves/plant}

Data on number of functioning leaves per plant recorded at 30, 60 days intervals up to maturity are represented in table 1 and Figure 2.

\section{Days to silking, tasselling and maturity}

\section{Days to silking}

It is apparent from the table- 1 and Figure 3 that day taken for silking was influenced significantly under fertility management practices. The higher days taken in silking was found in case of fertility management practices was recorded under $\mathrm{F}_{1}(100 \% \mathrm{RDF})$ and $\mathrm{O}_{3} \quad(25 \mathrm{t} \quad \mathrm{FYM} / \mathrm{ha})$ among the rest treatments.

\section{Days to tasseling}

It is clear from the table 1 and Figure 3 that days taken to tassel were influenced significantly under fertility management practices. The higher days taken to tassel under method of $\mathrm{F}_{1}$ and $\mathrm{O}_{3}$ which was at par with paired fertility management methods and lower in $\mathrm{F}_{3}$ and $\mathrm{O}_{1}$ whereas fertility management practices increased significantly higher days taken to tassel. These similar findings are in accordance with Arun and Singh (2004) and Kaundal and Sharma (2006).

\section{Days to maturity}

Pertaining the data on days to maturity is presented in table-1 and Figure 3 showed that days taken to maturity was found significantly higher under $\mathrm{F}_{1}$ and $\mathrm{O}_{3}$ method of fertility management than $\mathrm{F}_{3}$ and $\mathrm{O}_{1}$ method of $\mathrm{F}_{3}$ and $\mathrm{O}_{1}$. In respect of fertility management practices was recorded higher in $\mathrm{F}_{1}$ over rest of the fertilizer application. These similar findings are in accordance with Arun and Singh (2004) and Kaundal and Sharma (2006).

\section{Yield attributing characters}

The data pertaining to number of cobs per plant, length of cob $(\mathrm{cm})$, grains per cob, grain weight (g) per main cob and 1000-grain weight are presented in table- 2 and Figure 4. The result are in conformity with the findings 
of Singh et al., (1998), Nyamudeza et al., (2003), Singh et al., (2006) and Anjum et al., (2014).

\section{Number of cobs per plant}

The data on number of cobs/plant have been presented in table- 2 and Figure 4. It is evident that treatment of maize hybrid on $\mathrm{F}_{1}$ and $\mathrm{O}_{3}$ (100\% RDF and 25 t/ha FYM) significantly more number of cobs per plant over $\mathrm{F}_{3}$ and $\mathrm{O}_{1}$ (50\% RDF and 15 t/ha FYM) respectively. In case of fertility management practices $25 \mathrm{t}$ FYM along with $100 \%$ RDF produced higher number of cobs per plant than recommended dose of fertilizers.

\section{Length of $\operatorname{cob}(\mathrm{cm})$}

The data on average length of cob revealed that the treatment combination $\mathrm{F}_{1}$ and $\mathrm{O}_{3}$ (100\% RDF and 25 t/ha FYM) have better results over other treatment combination on length of cob (cm). Among the fertility management treatment combination $\mathrm{F}_{1}$ and $\mathrm{O}_{3}$ (100\% RDF and 25 t/ha FYM) registered significantly over $\mathrm{F}_{3}$ and $\mathrm{O}_{1}(50 \% \mathrm{RDF}$ and 15 t/ha FYM) respect to length of cob $(\mathrm{cm})$ respectively.

\section{Number of grains/ cob}

The data on number of grains per cob was presented in table-2 and Figure 4 which revealed that fertility management practices on number of grains per cob was influenced significantly.

In case of fertility management practices $F_{1}$ and $\mathrm{O}_{3}(100 \%$ RDF and 25t FYM/ ha) was superior over rest of the treatments. Similarly, $\mathrm{F}_{1}$ and $\mathrm{O}_{3}(100 \% \mathrm{RDF}$ and $25 \mathrm{t} / \mathrm{ha} \mathrm{FYM})$ application showed significant performance on grain row per cob over $\mathrm{F}_{3}$ and $\mathrm{O}_{1}(50 \% \mathrm{RDF}$ and 15 t/ha FYM) respectively.

Fig.1 Effect of fertility management practices on plant height $(\mathrm{cm})$ after 30, 60 days and at maturity of hybrid maize

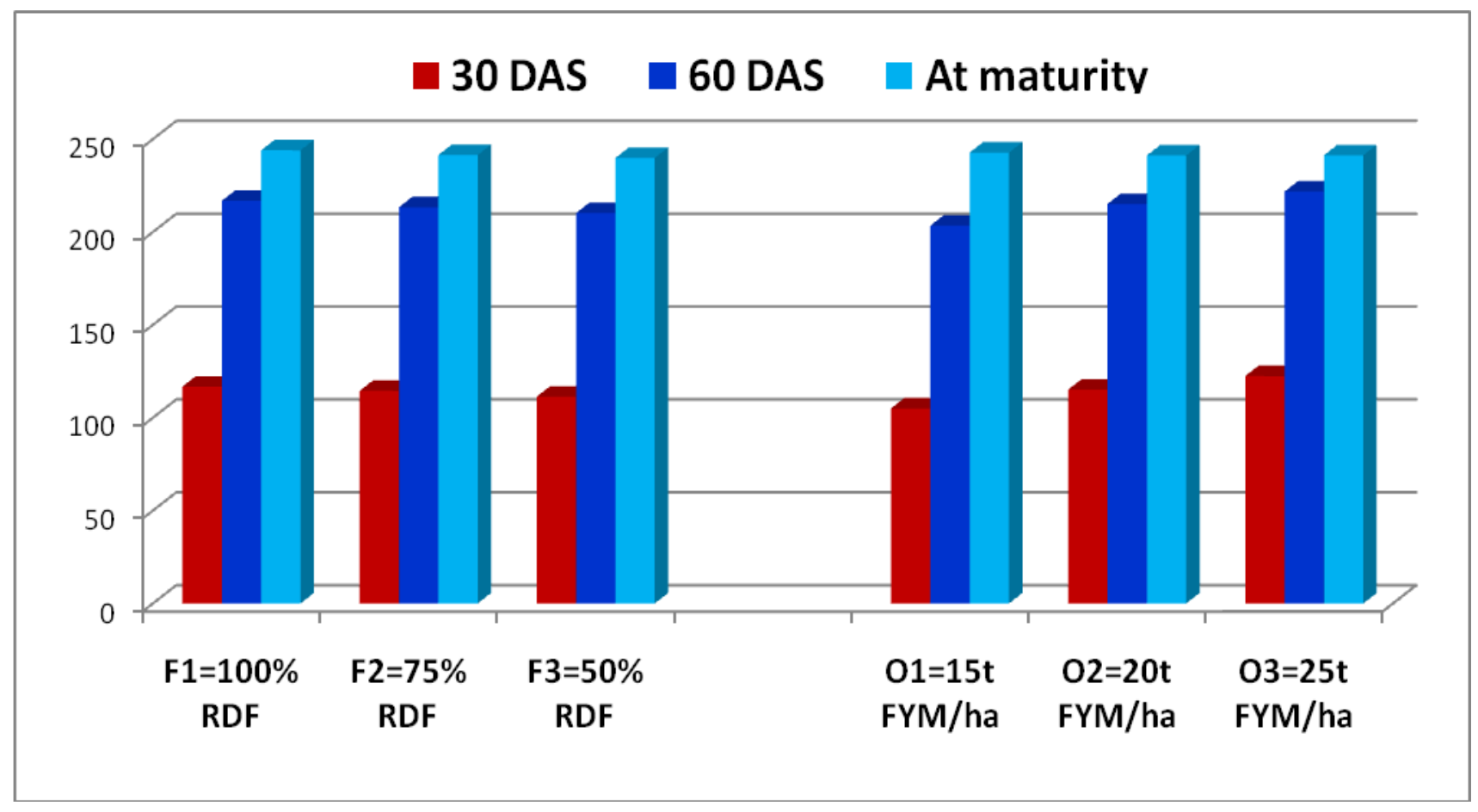


Fig.2 Effect of fertility management practices on no. of functional leaves/per plant after 30, 60 days and at maturity of hybrid Maize

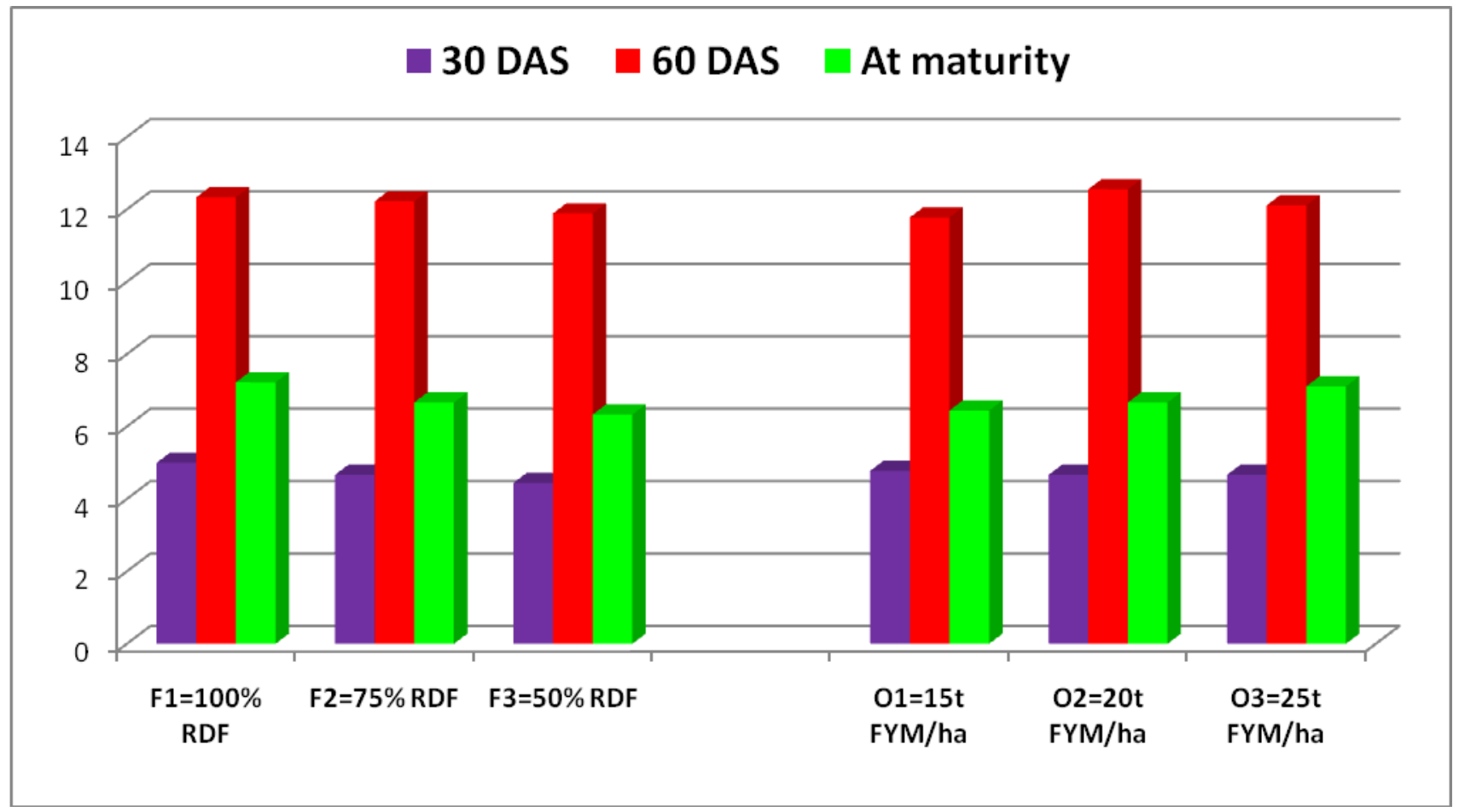

Fig.3 Effect fertility management practices on days to silking, days to tasseling and days to maturity

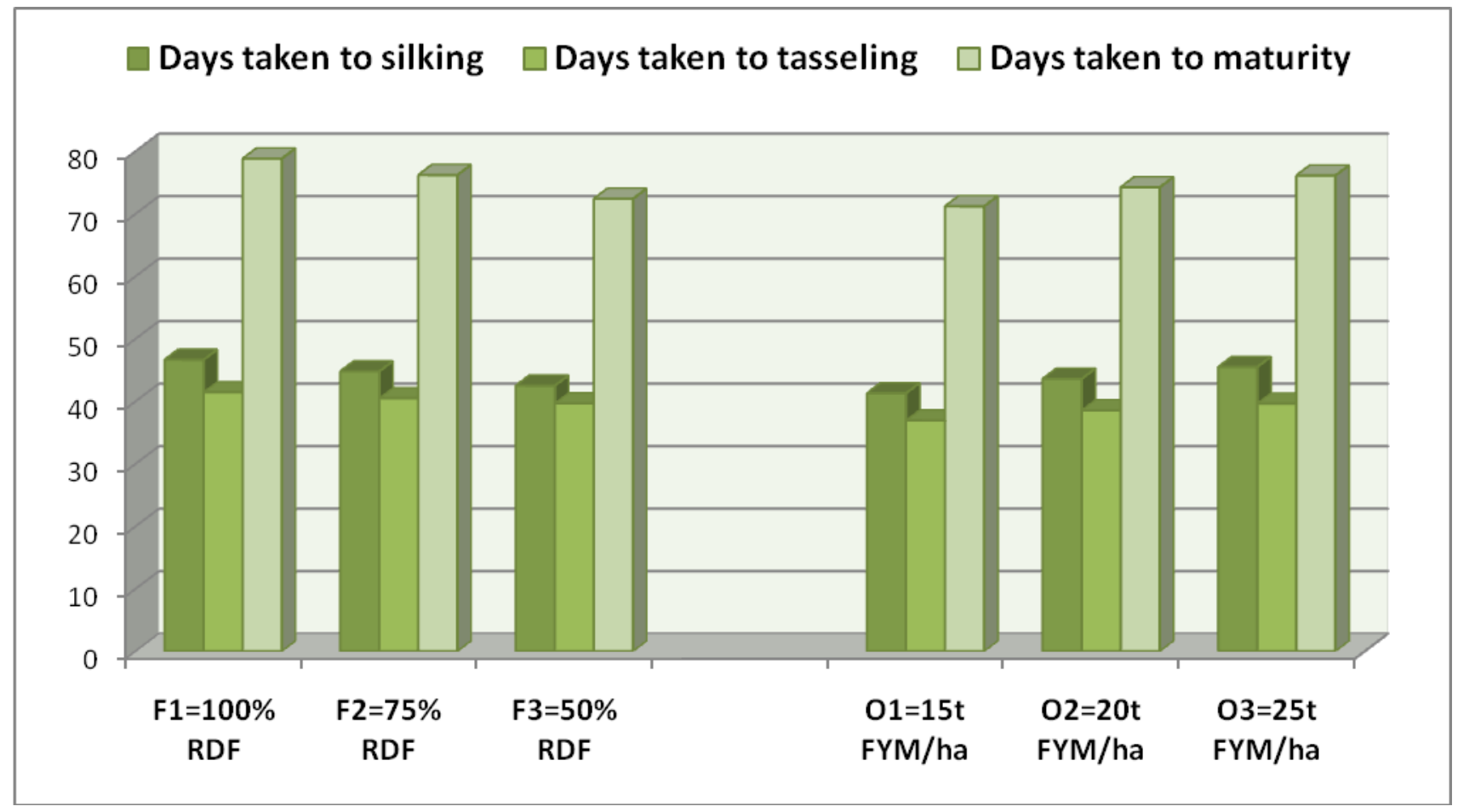


Fig.4 Effect of fertility management practices on number of cob/plant, length of cob (cm), no. of grains/cob, grain row /cob, girth of cob and 1000- grain weight (g) of hybrid maize

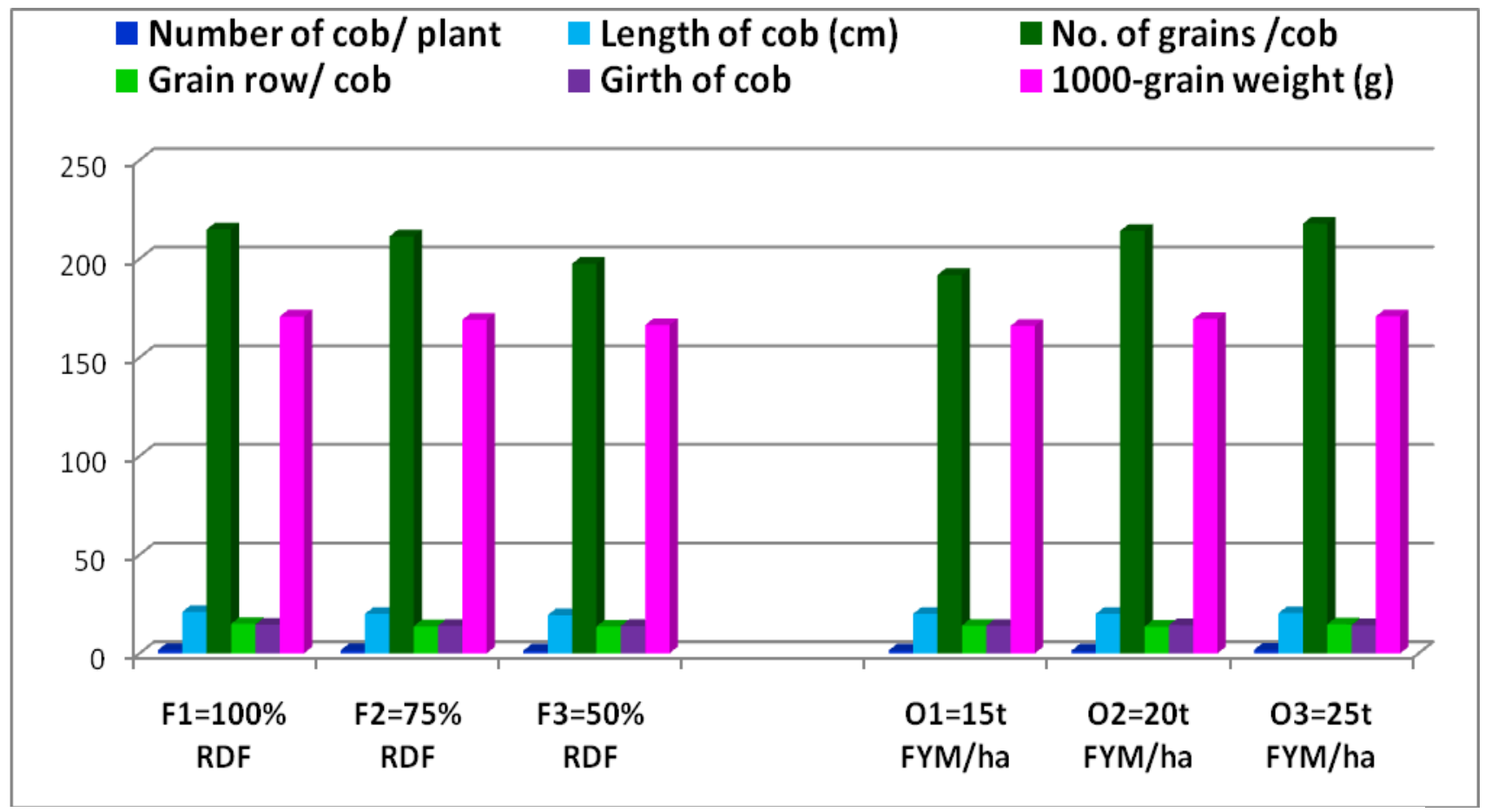

Fig.5 Effect of fertility management practices on yield (q/ha) and harvest index (\%) of hybrid maize

$\square$ Grain yield (q/ha) $\square$ Stover yield $(q / h a) \square$ Biomass Yield (q/ha) $\square$ Harvest Index (\%)

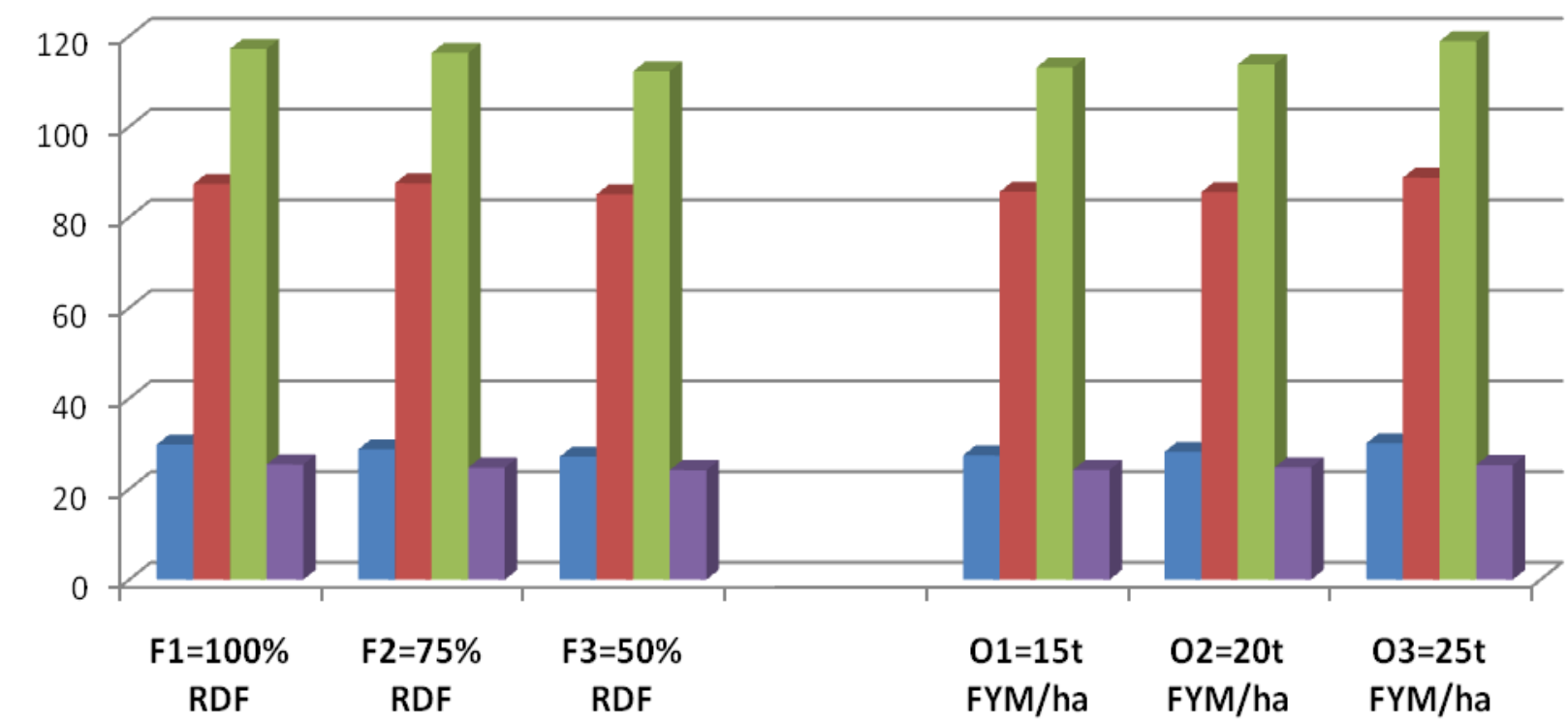


Fig.6 Water use $(\mathrm{mm})$ and water use efficiency $\left(\mathrm{kg}_{\mathrm{grain}} \mathrm{ha}^{-1} \mathrm{~mm}^{-1}\right.$ of water) on hybrid maize

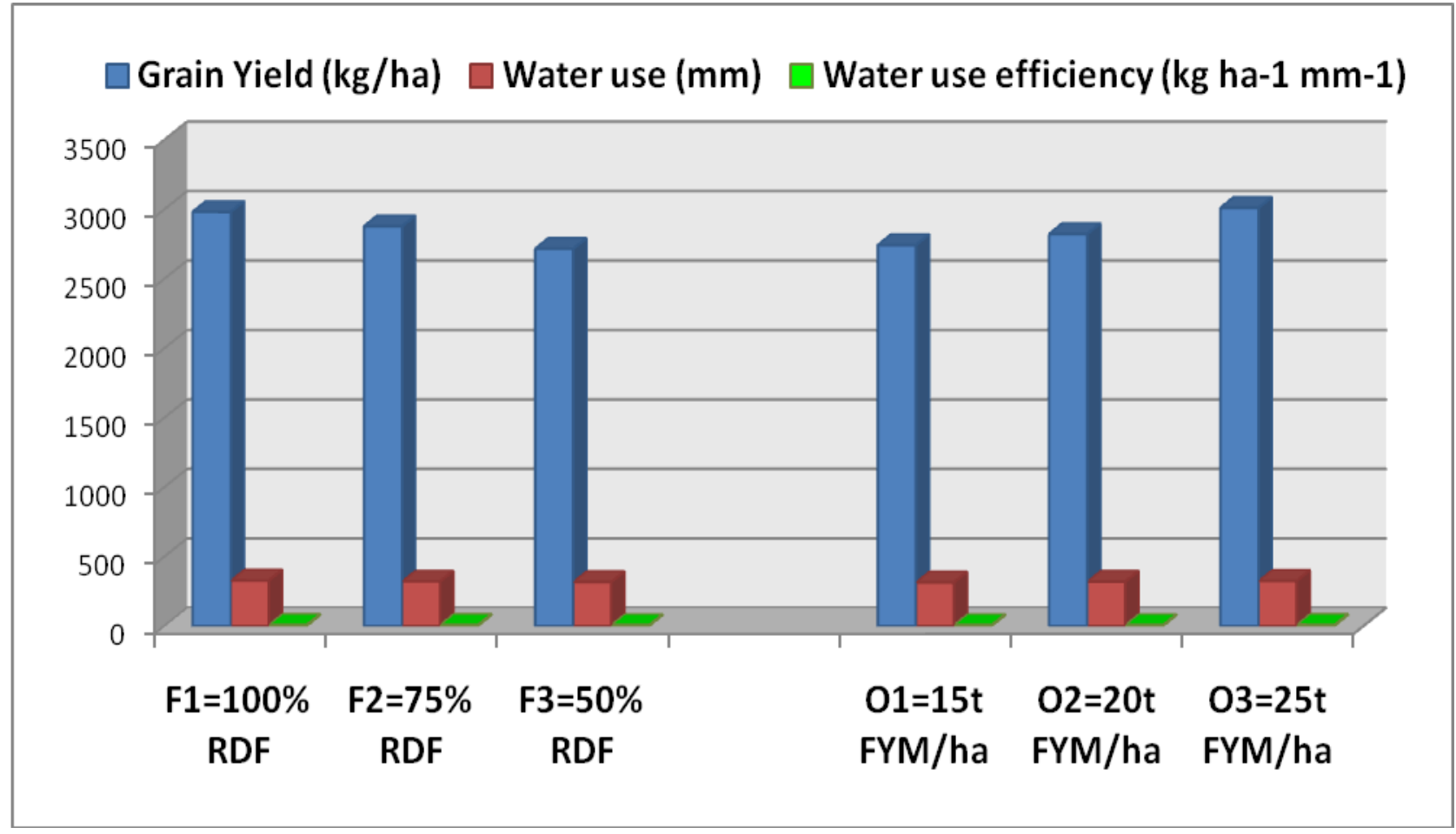

Fig.7 Treatment wise cost of cultivation of hybrid maize, gross income and Net return (in Rs. ha ${ }^{-1}$ )

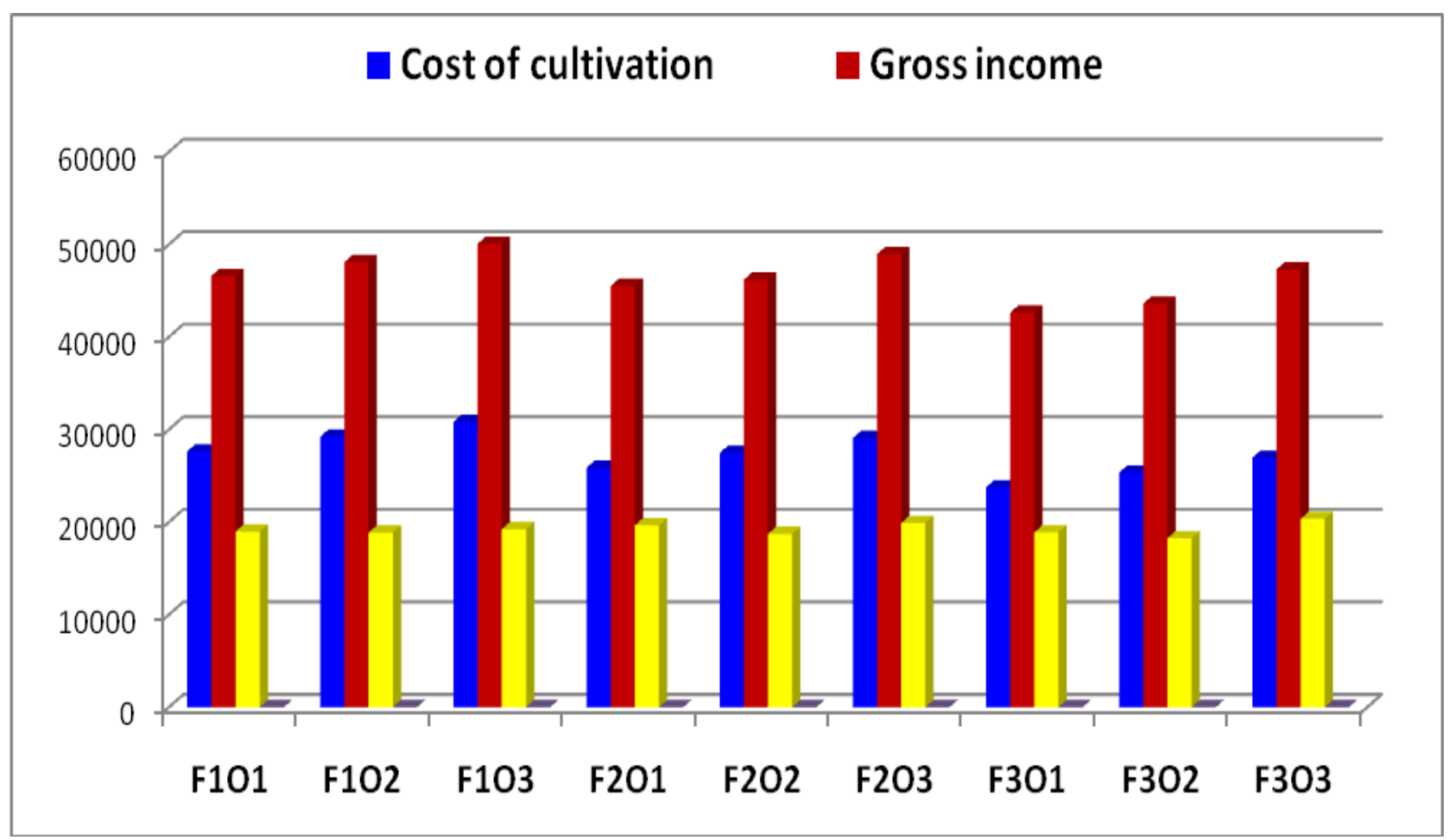


Table.1 Effect of fertility management (combination of Inorganic and Organic fertilizers (Kg/ha) practices on plant population $\left(000 \mathrm{ha}^{-1}\right)$, plant height $(\mathrm{cm})$, number of functional leaves/plant and day taken to silking, tasseling and maturity at during 2016

\begin{tabular}{|c|c|c|c|c|c|c|c|c|c|c|c|}
\hline \multirow[t]{2}{*}{ Treatment } & \multicolumn{2}{|c|}{$\begin{array}{l}\text { Plant population (000 } \\
\left.\text { ha }^{-1}\right)\end{array}$} & \multicolumn{3}{|c|}{ Plant height $(\mathrm{cm})$} & \multicolumn{3}{|c|}{ Number of functional leaves/plant } & \multicolumn{3}{|c|}{ Days taken to } \\
\hline & Initial & Final & 30 DAS & 60 DAS & Maturity & 30 DAS & 60 DAS & maturity & Silking & Tasseling & Maturity \\
\hline \multicolumn{12}{|c|}{ Levels of inorganic fertilizer } \\
\hline 100\% R.D.F. & 164.55 & 162.18 & 116.77 & 216.77 & 244.00 & 5.00 & 12.33 & 7.22 & 46.66 & 41.46 & 78.83 \\
\hline 75\% R.D.F. & 162.51 & 161.14 & 114.44 & 213.33 & 241.44 & 4.66 & 12.22 & 6.66 & 44.79 & 40.49 & 76.21 \\
\hline 50\% R.D.F. & 161.34 & 159.71 & 111.33 & 210.22 & 239.88 & 4.44 & 11.88 & 6.33 & 42.51 & 39.68 & 72.41 \\
\hline SE(d) & 3.45 & 2.89 & 1.57 & 2.31 & 1.41 & 0.2 & 0.30 & 0.27 & 0.55 & 0.49 & 0.88 \\
\hline C.D. $(P=0.05)$ & NS & NS & 3.34 & 4.90 & 2.99 & NS & $\mathrm{NS}$ & 0.57 & 1.66 & 1.48 & 2.67 \\
\hline \multicolumn{12}{|c|}{ Levels of organic manure } \\
\hline 15 ton FYM/ha & 162.61 & 161.23 & 105.00 & 203.44 & 242.77 & 4.77 & 11.77 & 6.44 & 41.3 & 36.96 & 71.21 \\
\hline 20 ton FYM/ha & 162.56 & 160.51 & 115.11 & 215.11 & 241.22 & 4.66 & 12.55 & 6.66 & 43.6 & 38.58 & 74.25 \\
\hline 25 ton FYM/ha & 163.23 & 161.29 & 122.44 & 221.77 & 241.33 & 4.66 & 12.11 & 7.11 & 45.5 & 39.66 & 76.13 \\
\hline SE(d) & 3.45 & 2.89 & 1.57 & 2.31 & 1.41 & 0.23 & 0.30 & 0.27 & 0.55 & 0.49 & 0.88 \\
\hline C.D. $(P=0.05)$ & NS & NS & 3.34 & 4.90 & NS & NS & NS & NS & 1.66 & 1.48 & 2.67 \\
\hline
\end{tabular}

Table.2 Effect of fertility management (combination of inorganic and organic fertilizers (Kg/ha) practices on number of cob/plant, length of cob $(\mathrm{cm})$, no. of grains/cob, grain row / cob, girth of cob and 1000- grain weight (g) of hybrid maize at during 2016

\begin{tabular}{|c|c|c|c|c|c|c|}
\hline Treatment & No. of cob/ plant & Length of cob $(\mathrm{cm})$ & No. of grains /cob & Grain row/ cob & Girth of cob & 1000-grain wt. (g) \\
\hline \multicolumn{7}{|c|}{ Levels of inorganic fertilizer } \\
\hline 100\% R.D.F. & 1.66 & 21.00 & 214.88 & 14.88 & 14.54 & 170.73 \\
\hline 75\% R.D.F. & 1.55 & 20.00 & 211.33 & 13.66 & 13.98 & 169.08 \\
\hline 50\% R.D.F. & 1.33 & 19.33 & 197.44 & 13.55 & 13.85 & 166.40 \\
\hline SE(d) & 0.18 & 0.31 & 3.41 & 0.29 & 0.19 & 0.91 \\
\hline C.D. $(P=0.05)$ & NS & 0.66 & 7.23 & 0.62 & 0.41 & 1.93 \\
\hline \multicolumn{7}{|c|}{ Levels of organic manure } \\
\hline 15 ton FYM/ha & 1.44 & 20.00 & 191.77 & 14.00 & 13.90 & 165.95 \\
\hline 20 ton FYM/ha & 1.33 & 20.00 & 214.11 & 13.44 & 14.26 & 169.44 \\
\hline 25 ton FYM/ha & 1.77 & 20.33 & 217.77 & 14.66 & 14.22 & 170.82 \\
\hline SE(d) & 0.18 & 0.31 & 3.41 & 0.29 & 0.19 & 0.91 \\
\hline C.D. $(P=0.05)$ & NS & NS & 7.23 & 0.62 & NS & 1.930 \\
\hline
\end{tabular}


Table.3 Effect of fertility management (combination of inorganic and organic fertilizers (Kg/ha) practices on yield (q/ha), harvest index $(\%)$, water use $(\mathrm{mm})$ and water use efficiency $\left(\mathrm{Kg} \mathrm{ha}^{-1} \mathrm{~mm}^{-1}\right)$ of hybrid maize at during 2016

\begin{tabular}{|c|c|c|c|c|c|c|}
\hline \multirow[t]{2}{*}{ Treatment } & \multicolumn{3}{|c|}{ Yield (q/ha) } & \multirow{2}{*}{$\begin{array}{l}\text { Harvest Index } \\
(\%)\end{array}$} & \multirow[t]{2}{*}{ Water use (mm) } & \multirow{2}{*}{$\begin{array}{c}\text { Water use } \\
\text { efficiency } \\
\left(\mathrm{kg} \mathrm{ha}^{-1} \mathrm{~mm}^{-1}\right)\end{array}$} \\
\hline & Biomass Yield & Stover yield & Grain yield & & & \\
\hline \multicolumn{7}{|c|}{ Levels of inorganic fertilizer } \\
\hline 100\% R.D.F. & 117.16 & 87.34 & 29.82 & 25.43 & 328 & 9.09 \\
\hline 75\% R.D.F. & 116.29 & 87.51 & 28.78 & 24.74 & 322 & 8.94 \\
\hline 50\% R.D.F. & 112.23 & 85.06 & 27.17 & 24.20 & 318 & 8.54 \\
\hline SE(d) & 0.96 & 0.81 & 0.21 & 0.213 & 328 & 9.09 \\
\hline C.D. $(P=0.05)$ & 2.05 & 1.72 & 0.45 & 0.45 & 322 & 8.94 \\
\hline \multicolumn{7}{|c|}{ Levels of organic manure } \\
\hline 15 ton FYM/ha & 113.06 & 85.62 & 27.43 & 24.25 & 318 & 8.62 \\
\hline 20 ton FYM/ha & 113.77 & 85.54 & 28.23 & 24.80 & 323 & 8.73 \\
\hline 25 ton FYM/ha & 118.85 & 88.74 & 30.10 & 25.32 & 327 & 9.20 \\
\hline SE(d) & 0.96 & 0.81 & 0.21 & 0.21 & 318 & 8.62 \\
\hline C.D. $(P=0.05)$ & 2.05 & 1.72 & 0.45 & 0.45 & 323 & 8.73 \\
\hline
\end{tabular}

Table.4 Treatment wise cost of cultivation of hybrid maize, gross income and net return (in Rs. ha ${ }^{-1}$ ) at during 2016

\begin{tabular}{|c|c|c|c|c|}
\hline Treatment & Cost of cultivation & Gross income & Net Return & 18961 \\
\hline $\mathrm{F}_{1} \mathrm{O}_{1}$ & 27626 & 46588 & 18865 & 2.46 \\
\hline $\mathrm{F}_{1} \mathrm{O}_{2}$ & 29226 & 48092 & 19231 & 2.55 \\
\hline $\mathrm{F}_{1} \mathrm{O}_{3}$ & 30826 & 50058 & 19650 & 2.60 \\
\hline $\mathrm{F}_{2} \mathrm{O}_{1}$ & 25863 & 45514 & 18724 & 2.32 \\
\hline $\mathrm{F}_{2} \mathrm{O}_{2}$ & 27463 & 46188 & 19887 & 2.47 \\
\hline $\mathrm{F}_{2} \mathrm{O}_{3}$ & 29063 & 48951 & 2.46 \\
\hline $\mathrm{F}_{3} \mathrm{O}_{1}$ & 23744 & 42633 & 2.26 \\
\hline $\mathrm{F}_{3} \mathrm{O}_{2}$ & 25344 & 43597 & 20344 \\
\hline $\mathrm{F}_{3} \mathrm{O}_{3}$ & 26944 & 47288 & 2.39 \\
\hline
\end{tabular}




\section{Grain weight per cob (g)}

The data pertaining to grain weight per cob is presented in table- 2 and Figure 4 showed that fertility management practices influenced significantly higher grain weight $(\mathrm{g})$ per cob of hybrid maize.

The fertility management treatment $\mathrm{F}_{1}$ and $\mathrm{O}_{3}$ (100\% RDF and 25t FYM/ ha) was superior over all others treatments and achieved significantly higher value than other treatments. In case of fertility management practices 25 t/ha FYM along with $100 \% \mathrm{RDF}$ was attended higher value than $\mathrm{F}_{3}$ and $\mathrm{O}_{1}$ (50\% RDF and 15 t/ha FYM) respectively.

\section{0-grain weight $(g)$}

It is evident from the data given in table- 2 and Figure 4 that 1000-grain weight was influenced significantly under method of higher fertility management practices. 1000 grain weight was maximum recorded under $\mathrm{F}_{1}$ and $\mathrm{O}_{3}(100 \% \mathrm{RDF}$ and 25 Ton FYM /ha) practices than other combinations treatments.

In case of fertility management practices on 1000 grain weight was found higher i.e. $170.67(\mathrm{q} / \mathrm{ha})$ with $\mathrm{F}_{1}$ and $\mathrm{O}_{3}$ followed by other combinations and lowest in $\mathrm{F}_{1}$ and $\mathrm{O}_{3}$ treatment respectively.

\section{Girth of cob (cm)}

Effect of fertility management practices on girth of cob $(\mathrm{cm})$ at maturity stage of the crop presented in the Table table- 2 and Figure 4 showed that the girth of cob $(\mathrm{cm})$ was influenced significantly under fertility management practices.

The maximum girth was recorded under $\mathrm{F}_{1}$ and $\mathrm{O}_{3}(100 \% \mathrm{RDF}$ and 25t/ha FYM) and lower in $\mathrm{F}_{3}$ and $\mathrm{O}_{1}(50 \% \mathrm{RDF}$ and $15 \mathrm{t} / \mathrm{ha}$ FYM) at maturity stage of crop.

\section{Yield}

\section{Biomass yield (q/ha)}

It is apparent from the data given in table-3 and Figure 5 that fertility management practices was significantly superior over the $\mathrm{F}_{1}$ and $\mathrm{O}_{3}$ and obtained higher biomass yield (117.16 q/ha and $118.85 \mathrm{q} / \mathrm{ha}$ ) while lower in $\mathrm{F}_{3}$ and $\mathrm{O}_{1}(112.23 \mathrm{q} / \mathrm{ha}$ and $113.06 \mathrm{q} / \mathrm{ha})$. In case of fertility management practices was found significantly higher biomass yield in $\mathrm{F}_{1}$ and $\mathrm{O}_{3}(100 \% \mathrm{RDF}$ and $25 \mathrm{t} \mathrm{FYM} / \mathrm{ha})$ in comparison to other fertility management practices (Ahmad et al., 2008; Verma and Midha, 2006; Chaudhary et al., 2008).

\section{Stover Yield (q/ha)}

It is evident from the data given in table- 3 and Figure 5 that stover yield was influenced significantly under fertility management practices. The highest stover yield was recorded $87.34 \mathrm{q} / \mathrm{ha}$ and $88.74 \mathrm{q} / \mathrm{ha}$ in $\mathrm{F}_{1}$ and $\mathrm{O}_{3}$ (100\% RDF and 25 Ton FYM /ha) respectively in comparison of other treatments of hybrid maize. Under fertility management practices $\mathrm{F} 3$ and $\mathrm{O} 1$ (50\% RDF and 15 Ton FYM /ha) grasped lower stover yield i.e. $85.06 \mathrm{q} / \mathrm{ha}$ and $85.62 \mathrm{q} / \mathrm{ha}$ as compared to others. Similar findings had also been reported by Kumar et al., (2008).

\section{Grain Yield (q/ha)}

It is clear from the data given in table- 3 and Figure 5 that grain yield was influenced significantly under fertility management practices. The highest grain yield was recorded under $\mathrm{F}_{1}$ and $\mathrm{O}_{3}(100 \% \mathrm{RDF}$ and 25 Ton FYM/ha) $29.82 \mathrm{q} / \mathrm{ha}$ and $30.10 \mathrm{q} / \mathrm{ha}$ from fertility management parameter as compared to $\mathrm{F}_{3}$ and $\mathrm{O}_{1}(50 \% \mathrm{RDF}$ and 15 Ton FYM /ha) of treatment $(24.20 \mathrm{q} / \mathrm{ha}$ and $24.25 \mathrm{q} / \mathrm{ha})$ respectively (Ahmad et al., 2008; Verma and Midha, 2006; Chaudhary et al., 2008). 


\section{Harvest index (\%)}

It is clear from the data given in the table-3 and Figure 5 showed that harvest index (\%) was influenced under fertility management practices. The maximum harvest index 25.43 and 25.32 was found in $\mathrm{F}_{1}$ and $\mathrm{O}_{3}(100 \% \mathrm{RDF}$ and $25 \mathrm{t} F Y M / h a)$ as compared to other treatments. The view is supported by the findings of Wani et al., (1997), Mahale et al., (1998), Jat and Gautam (2000) and Memon et al., (2007).

\section{Water use and water use efficiency}

Data pertaining to total water use and water use efficiency of hybrid maize crop have been given in table 3 and Figure 6 . The water use efficiency was recorded at different fertility management practices. The $\mathrm{F}_{1}$ i.e. $100 \% \mathrm{RDF}$ treatment of fertility was recorded higher water use efficiency as compared to other practices. Whereas, organic manures data depicted in Table 4.7 showed highest water use efficiency with $\mathrm{O}_{3}$ and followed $\mathrm{O}_{2}$ however lowest value was observed in case of $\mathrm{O}_{1}$. The result is in full agreement with the findings of Parihar et al., (2003).

\section{Economics}

Data pertaining to economics of different treatment are summarized in table 4 and Figure 7. Both fertility management practices registered higher net return over $\left(\mathrm{F}_{1}\right.$ and $\left.\mathrm{O}_{3}\right)$. The highest net return of Rs. 19231.45/ha was obtained from the treatment $\left(\mathrm{F}_{1}\right.$ and $\left.\mathrm{O}_{3}\right)$ respectively. Highest B: C ratio 2.60 was found in $\left(\mathrm{F}_{1}\right.$ and $\left.\mathrm{O}_{3}\right)$ treatment as compared to rest treatments and combined fertility management practices. Similar observations were recorded by Suroshe et al., (2009).

Different fertility levels played significant role in increasing all growth characters viz. plant population among the fertility levels the
$\mathrm{F}_{1}+\mathrm{O}_{3}(100 \% \mathrm{RDF}+25 \mathrm{t} \mathrm{FYM} / \mathrm{ha})$ enhanced the plant population. The inorganic fertilizer applications of $100 \% \mathrm{RDF}+25 \mathrm{t} \mathrm{FYM} / \mathrm{ha}$ were found most effective in respect to plant height and number of functioning leaves per plant. The maximum number of cobs per plant, length of cob $(\mathrm{cm})$, number of grains per cob, grain weight $(\mathrm{g})$ per cob, 1000 grain weight were recorded and highest reported under the fertility level of $100 \% \mathrm{RDF}+25 \mathrm{t}$ FYM/ha followed by $75 \%$ RDF $+20 \mathrm{t}$ $\mathrm{FYM} / \mathrm{ha}$ and $50 \% \mathrm{RDF}+15 \mathrm{t} \mathrm{FYM} / \mathrm{ha}$ in combination. Grain, biomass and stover yield were significantly increased with increasing levels of fertility. The water use and water use efficiency was recorded at different fertility management practices. The $100 \%$ RDF treatment of fertility was recorded higher water use efficiency as compared to other treatments. Both the fertility management practices registered higher net return over other treatments. The highest net return of Rs. $19231 \mathrm{ha}^{-1}$ was obtained from the treatment $\mathrm{F}_{1}$ $(100 \% \mathrm{RDF})$ and $\mathrm{O}_{3}(25 \mathrm{t} \mathrm{FYM} / \mathrm{ha})$ and lowest of Rs. 18888 ha $^{-1}$ with $\mathrm{F}_{3}(50 \% \mathrm{RDF})$ and $\mathrm{O}_{1}(15 \mathrm{t} \mathrm{FYM} / \mathrm{ha})$ treatments. However, highest $\mathrm{B}$ : $\mathrm{C}$ ratio 2.60 was found in $\mathrm{F}_{1}(100 \%$ $\mathrm{RDF})$ and $\mathrm{O}_{3}(25 \mathrm{t} \mathrm{FYM} / \mathrm{ha})$ technique as compared to rest fertility management practices. On the overall consideration of results described and discussed in the preceding chapters, it can be concluded that in the case of fertility levels $100 \% \mathrm{RDF}+25 \mathrm{t}$ $\mathrm{FYM} / \mathrm{ha}\left(\mathrm{F}_{1}+\mathrm{O}_{3}\right)$ was found better in all respect as compared to other combinations of fertility management. So, it may be recommended that growing of hybrid maize crop in Kharif season was found most suitable and remunerative in central plain zone of Uttar Pradesh in Kanpur.

\section{Acknowledgements}

With limitless humility, I bow my head to Almighty, Merciful Compassionate and Supreme power 'God' who showered his 
mercy on me and blessed me with the favorable circumstances to go through his gigantic task. I feel golden opportunity with great pleasure in acknowledging my profound sense of veneration and gratitude to my major advisor and Chairman, Dr. Munish Kumar, Professor. The authors are thankful to the Head, Department for providing the required research facilities. I gratefully express my deep sense gratifies to my respected seniors Mr. Raj Kumar Department of Soil Conservation and Water Management, Chandra Shekhar Azad University of Agriculture and Technology, Kanpur,(U.P.) India for his keen interest, valuable guidance, and constructive criticism throughout the pursuit of the present research and vital suggestion during preparation of this manuscript.

\section{References}

Amanolahi- Baharvand, Z., Zahedi, H. and Rafiee, M. (2014). Effect of vermicompost and chemical fertilizers on growth parameters of three corn cultivation. J. Applied Science and Agriculter.9 (9): 22-26.

Amoh, A.A, Senge, M, Miyagawa, S. And Itou, K. (2012). Effect of soil fertility management on growth, yield and water - use efficiency of maize (Zea mays L.) and selected soil properties. Communication in soil Science and plant Analysis. 43(6): 924-935.

Anjum, S.A., Ehsanullah; Umair Ashraf; Mohsin Tanveer; Rafi Qamar; Imran Khan(2014). Morphological and phonological attributed of maize affected by different tillage practices and varied sowing method. American J. of Plant Sciences. 5(11): 1657-1664.

Anonymous (2010). All India Co-ordinated Research Project, Directorate of maize research, New Delhi.

Auwal Tukur Wailare (2014). Effect of Integrated Nutrient Management on Baby Corn (Zea mays L.) - A Review, International Journal of Science and Research (I.J.S.R.). 3(6): 22182222.

Azhar Ghaffari, Asghar Ali, Muhammad Tahir, Muhammad Waseem, Muhammad Ayub, Asif Iqbal and Atta Ullah Mohsin. (2011). Influence of integrated nutrients on growth, yield and quality of maize (Zea mays L.). American Journal of Plant Sciences. 2: 63 - 69 .

Balai ML, Verma A., Nepalia V. and Kanthaliya P.C. (2011). Productivity and quality of maize (Zea mays L.) as influenced by integrated nutrient management under continuous cropping and fertilization. Indian Journal of Agricultural Sciences. 81:374-376.

Bhan, S. and Singh, S.R. (1979). Water harvesting and moisture conservation practices for dry farming of maize and mustard in U.P. Annals Arid Zone, 18 (1 and 2): 101-107.

Das A., Lenka N.K., Sudhishri S and Patnaik U.S. (2008). Influence of integrated nutrient management on production, economics and soil properties in tomato (Lycopersicon esculentum) under on-farm condition in Eastern Ghats of Orissa. Indian Journal of Agricultural Sciences. 78: 40-43.

Ghosh A. K., Dass, A., Kaur, R and Kumar, A (2016). Yield components and nutrient accumulation in maize (Zea mays) under variable growing environments and chlorophyll meter-guided nitrogen fertilization.: Indian Journal of Agronomy. 61(2): 252-255.

Kalhapure, A.H., Shete, B.T. and Dhonde, M.B. (2013). Integrated Nutrient Management in Maize (Zea Mays L.) for Increasing Production with Sustainability. International Journal of Agriculture and Food Science Technology. 3 (4): 195-206.

Khan, M.B., Farhan Yousaf, Mubshar Hussain, Haq, M.W., Lee, D.J., Muhammad Farooq. (2012). Influence of planting methods on root development, crop productivity and water use efficiency in maize hybrids. Chilean J. Of Agricultural Research. 72 (4): 556-563.

Khan, M.B., Rafiq, R., Hussain, M., Farooq, M., Jabran, K. (2012). Ridge sowing improves root system, phosphorus uptake, growth and yield of maize (Zea mays L.) hybrids. JAPS, Journal of Animal and Plant Sciences 2012 Vol. 22 No. 2 pp. 309-317.

Kumar, R., Bohra, J.S., Kumawat, N. and Singh, A.K. (2015). Fodder yield, nutrient uptake and quality of baby corn (Zea mays L.) as influenced by NPKS and Zn fertilization. Res. Crops, 16:243-24,

Lalrammuanpuia Hnamte, C. Lalrammawia and B. Gopichand (2016). Effect of NPK fertilizer on growth and yield of maize under different jhum 
cycles in Mizoram. Science Vision 16 (2):5967.

Lourduraj AC (2006). Identification of optimum quantity of vermi-compost for maize under different levels of fertilization. Journal of Ecobiology, 18(1): 23-27.

Manea, M.A., Avijit Sen; Upadhyay, P.K, Yashwant Singh, Srivastava, V.K. Singh, R.K. (2015). Effect of fertility levels and planting methods on growth and nutrient removed by pre kharif baby corn (Zea mays L.) Varieties. $J$. Environment and Ecology. 33 (2): 734-738.

Manjhi, R.P., Yadava, M.S., Thakur, R. (2014). Effect of integrated nutrient management on crop productivity and changes in soil fertility in maize (zea mays)- wheat (Triticum aestivum) cropping sequence. Indian J. of agronomy.59 (3): 371-376.

Mohammed Awad., Samir Al Solaimani G, Fathy ElNakhlawy S. (2014). Effect of integrated use of organic and in organic fertilizers on NPK uptake efficiency by maize [Zea mays.(L)], International Journal of Applied Research and Studies (IJARS), 3(7): 2278-9480.

Rajeshwar Malavath and Ramulu. (2014) Effect of soil amendments relation to soil water relation capacity and soil fertility in maize in albisol of NPK left canal command area. Asian J. Soil Sci. 9 (3): 371-376.

Shahid Rasool, R. H., Kanth, Shabana Hamid, W. Raja, B. A. Alie and Z. A. Dar (2015). Influence of Integrated Nutrient Management on Growth and Yield of Sweet Corn (Zea mays L. saccharata) under Temperate Conditions of Kashmir Valley. American Journal of Experimental Agriculture. 7 (5): 315-325.

Singh, G., Singh, N. and Kaur, R. (2016a). Effect of integrated nutrient management on yield and quality parameters of baby corn (Zea mays L.). Intern J. Appl. Pure Sci. Agri., 2:161-166.

Singh, R.N., Nath, N. N., Singh, S.K., Mohan, T.K., Shahi, J.P. (2006). Effect of agronomic management practices on growth, yield and quality of Kharif maize (Zea mays L.) under excessive moisture condition. Crop Research (Hisar). 32. (3).302-305.

Singh, R.P., Yadav, P.N., Uttam, S.K., Katiyar, S.C., and Tripathi, A.K. (2012) Effect of moisture conservation and nutrient management on growth, yield and water use efficiency of sorghum (Sorghum bicolour) under rainfed condition. Current Advances in Agric. Sci. 4 (1): $37-40$.

Stulin AF (2012). Effects of fertilization on productivity of maize in Voronezh region. Kukuruzai Sorgo, 1:19- 24.

Thirupathi I., G.E. Ch. Vidya Sagar, K.B. Suneetha Devi and S. Harish Kumar Sharma (2016). Effect of nitrogen and sulphur levels on growth, yield, quality and economics of single cross hybrid maize (Zea mays L) International Journal of Science, Environment and Technology, 5 (5): 2989 - 2998.

Umesha S., Srikantaiah M., Prasanna K. S, Sreeramulu K.R., Divya M. and Lakshmipathi R.N. (2014). Comparative Effect of Organics and Bio-fertilizers on Growth and Yield of Maize (Zea mays L). Current Agriculture Research Journal 2 (1), 55-62.

Venkata Rao P., Subbaiah G and Veeraraghavaiah, R. (2013). Agronomic responses of maize to plant population and nitrogen availability- $A$ review IJPAES. 4 (1): 107-116.

Yadav Ajay Kumar, Subash Chand and O.V.S. Thenua (2016). Effect of integrated nutrient management on productivity of maize with mungbean intercropping. G.J.B.B, 5 (1): 115118.

Zamir, M. S. I., Yasin, G., Javeed, H. M. R; Ahmad, A. U. H; Tanveer, A. And Yaseem, M. (2013). Effect of different sowing techniques and mulches on growth and yield of maize (Zea mays L). J. Cerceta Agronomice in Moldova. 46 (1): 77-82.

\section{How to cite this article:}

Durgesh Kumar, Munish Kumar and Raj Kumar. 2018. Evaluate the Integrated Nutrient Use on Growth and Yield of Hybrid Maize under Central Plain Zone of Uttar Pradesh, India. Int.J.Curr.Microbiol.App.Sci. 7(03): 518-530. doi: https://doi.org/10.20546/ijcmas.2018.703.062 